\title{
JĘZYK POLITYKI JAKO PODSTAWOWE NARZĘDZIE DZIAŁANIA POLITYCZNEGO I NIEODLĄCZNY ATRYBUT WLADZY W ŚWIETLE PRODUKCJI DYSKURSU PRAWDZIWOŚCIOWEGO
}

\author{
„Historia nieustannie dowodzi, że dyskurs jest nie tylko \\ czymś, co tłumaczy walki i systemy panowania, \\ lecz również tym, dla czego, poprzez co walczymy \\ - jest władzą, którą usiłujemy zdobyć."1
}

\begin{abstract}
$\mathrm{D}$ yskurs polityczny jako specyficzny rodzaj wytwarzanego słowa towarzyszy ludzkości odkąd zdołała ona skupić się w formie zorganizowanej struktury - czy to plemiennej, państwowej, czy międzynarodowej. Warunkiem sine qua non powstania i trwania owej struktury było równocześnie stworzenie odpowiedniego języka, ogarniającego swą moca wszelkie aspekty życia społecznego. W każdym więc społeczeństwie, wytwarzanie dyskursu miało $i$ ma na celu „równocześnie kontrolowanie, selekcjonowanie, organizowanie i poddanie redystrybucji przez pewną liczbę procedur, których rolą jest zaklinać moce i niebezpieczeństwa, zawładnąć przypadkowościa zdarzeń"

Tak też prym w wytwarzaniu i redystrybucji dyskursu politycznego wiodą elity polityczne, które w różny sposób (najczęściej siłowytotalitarny; autorytarny bądź perswazyjny) starają się ukazać prawdziwość
\end{abstract}

\footnotetext{
${ }^{1}$ M. Foucault, Porzadek dyskursu. Stowo/Obraz / Terytoria, Warszawa 2002, s. 8
}

2 Tamże, s. 7. 
dyskursu. W przeszłości rolę taką spełniali kapłani, szamani, rady starszych. Bardzo często posługiwano się metafizycznym czynnikiem tworzenia dyskursu. Przykładem może być choćby słynne hasło przyświecające pierwszej wyprawie krzyżowej - „Bóg tak chce”. Takie narzędzie stawało się niebywale potężne w swej prostocie a zaangażowanie jej adresatów, które było czymś więcej niż tylko zaangażowaniem emocjonalnym, utwierdzało prawdziwość i nieodwołalność jakoby Boskiego słowa. W czasach monarchii absolutystycznych dyskurs polityczny został bardzo ograniczony, tak jak w późniejszych państwach totalitarnych; $z$ tą jednak różnica, że tutaj dyskurs permanentnie produkowano, modyfikowano i zmieniano jego znaczenie, tam zaś wystarczyło powiedzieć: „Państwo to Ja” i dyskurs się zamykał.

Językowi polityki bardzo często towarzyszy manipulacja nim. „Manipulowanie językiem w polityce występuje na szeroka skalę i pojawia się już w momencie, gdy polityk zastanawia się, jakiego użyć języka, aby skutecznie trafić do odbiorcy"’3. Dlatego też wypowiedzi publiczne polityków nie mają najczęściej charakteru spontanicznego, lecz są pragmatycznie skierowane na cel; ,komunikowanie polityczne jest jakby zabiegiem rytualnym, wobec tego traca sens tradycyjne standardy oceny informacji jako prawdziwe bądź nie" ${ }^{\text {"4 }}$. Analizując dyskurs, należy zwrócić szczególną uwage również na podmiot wypowiadający (potencjalnie manipulujący), ażeby nie popełnić błędu kardynalnego, gdyż często jako obserwatorzy tracimy z oczu fakt, że każda jednostka odgrywa wiele ról społecznych, chociaż my możemy obserwować tylko jedną $z$ nich. ${ }^{5}$ Charakter manipulacji językiem politycznym do złudzenia przypomina zalecenia Niccolo Machiavellego, który także przestrzegał przed jednoznaczna interpretacją zachowań władcy: „Ludzie w ogóle więcej osądzają oczyma niż rękoma, bo widzieć dane jest każdemu, a dotykać niewielu, każdy widzi, za jakiego uchodzisz, lecz bardzo mało wie, czym jestes" ". To, co nazywam tutaj manipulacją Gary Woodward pięknie nazywa korupcja dyskursu politycznego, przedstawiając jej cztery odmiany: przymus, oszustwo, mistyfikację oraz przesunięcie znaczeniowe. $^{7}$

3 P. Pawełczyk, Socjotechniczne aspekty gry politycznej, Wydawnictwo Naukowe UAM, Poznań 2000, s.171.

${ }^{4}$ Tamże, s.174.

${ }^{5}$ E. Aronson, Cztowiek istota spoteczna, PWN, Warszawa 1995, s.201.

${ }^{6}$ N. Machiavelli, Ksiqże, PIW, Warszawa 1984, s. 88.

${ }^{7}$ G.C. Woodward, Korupcja dyskursu politycznego: jej cztery odmiany, w: Wtadza i spoteczeństwo, J. Szczupaczyński (red.), SCHOLAR, Warszawa 1995, s.207. 
Cała przedstawiona wyżej „prawdziwościowość”, „manipulacja” czy „korupcja” świadczą o specyficznej dychotomiczności dyskursu politycznego, która wydaje się być nieunikniona. Polega ona na przeciwstawieniu dyskursu narracyjnego - opartego wyłącznie na faktach, który „ogranicza się do relacjonowania wydarzeń i nie pozostawia miejsca dla jakichkolwiek interpretatorskich czy wyjaśniających naddatków" - dyskursowi ideologicznemu (wartościującemu). „Pojawiają się także ciagłe próby narracyjnego wykorzystania mowy ideologicznej, aby uformować opowiadanie, które nie tyle mówi o faktach, ile podsuwa ich oceny"'.

W tej pracy ukażę produkcję dyskursu prawdziwościowego, będąca podstawowym elementem działania politycznego i nieodłącznym atrybutem władzy. Przedstawię formę dyskursu ideologicznego, którego immanentna cecha jest stwierdzanie swojej prawdziwości - na przekór temu, że takowej nie sposób jednoznacznie stwierdzić. Wiąże się więc to ze swoistą absurdalnością oceny jego prawdziwości. W związku z tym, że forma dyskursu narracyjnego zanika i zajmuje niewiele miejsca na scenie politycznej (choć paradoksalnie jest najbardziej pożądaną forma przekazu dla odbiorców), w dalszej części pracy, pisząc o dyskursie politycznym, będę miał na myśli jego ideologiczną formę. Tę właśnie, która daje miejsce do owych interpretatorskich i wyjaśniających naddatków, która wartościuje fakty, manipuluje nimi i pozwala zdobyć to, o co ciagle toczy się walka - o władzę.

W pierwszych latach Polski ludowej próbowano znaleźć podstawę ideologiczna dla kształcenia najmłodszych obywateli. W powszechnym mniemaniu podstawę taką prezentował humanizm, ale niestety łączył on w sobie chrześcijańską miłość bliźniego. Należało więc dokonać zabiegu przesunięcia znaczeniowego i dokonano tego. Powstał nowy humanizm - humanizm socjalistyczny; przeciwstawiono go chrześcijańskiej miłości bliźniego:

[...] hasło miłości bliźniego nie określa, o jakiego człowieka chodzi. Ogólnie nazywamy wszystkich ludzi bliźnimi. Czy kochamy Trumana? Nie. Ale Truman przecież jest bliźnim. [...] My kochamy naprawdę człowieka. Nie kochamy bestii, kochamy człowieka pracy, a nienawidzimy wyzyskiwaczy, krzywdzicieli. Mówimy wyraźnie: w walce klasowej będziemy brać najwyższy udział po to, aby przyspieszyć istnienie społeczeństwa bezklasowego, w którym

8 M. Głowiński, Rytuat i demagogia. Trzynaście szkeiców o sz̨uce zdegradowanej, OPEN, Warszawa 1992, s. 19

${ }^{9}$ Tamże. 
dopiero w pełni będzie mogło znaleźć zastosowanie piękne i wzruszające hasło miłości człowieka. A więc nasz humanizm socjalistyczny mówi wyraźnie: Nasz stosunek do człowieka polega na tym, że pomagamy tym, którzy pracuja, przeciwko tym, którzy wyzyskują. ${ }^{10}$

Następnie próbowano w jakiś sposób załagodzić znaczenie słowa „nienawiść” więc przekonywano, że nienawiść do wrogów ludu jest rzeczą naturalna:

Dziecko wie, że miłość idzie w parze z nienawiścią. [...] To są rzeczy nierozdzielne. Jeżeli coś mocno kochamy, to nienawidzimy tego, co niszczy przedmiot naszego ukochania i dlatego nasza nienawiść - to jest nienawiść do zła, do krzywdy, to jest piękna nienawiść. Nie trzeba się obawiać takiej nienawiści jako hasła wychowawczego. ${ }^{11}$

Właśnie ten „prawdziwy” humanizm socjalistyczny stał się hasłem wychowawczym, a dyskurs polityczny wprowadzono z całą siłą do szkół. Tak też, kiedy pojawił się plan sześcioletni, równocześnie ukazała się książeczka dla dzieci $\mathrm{O}$ sześcioletnim Bronku i Sześcioletnim Planie. ${ }^{12}$ Bardzo ważną kwestią w wychowaniu socjalistycznym było również tworzenie peanów na część bohaterów socjalizmu, na przykład:

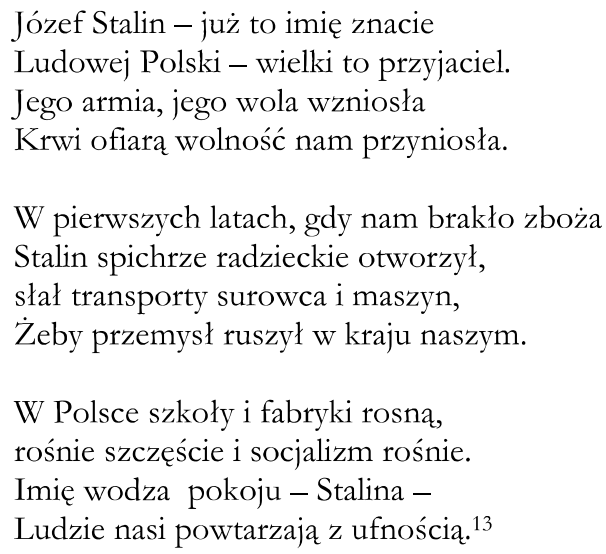

10 Cyt. za: M. Brodala, Propaganda dla najmłodszych w latach 1948-1956. Instrument stalinowskiego wychowania; w: M. Brodala, A. Lisiecka, T. Ruzikowski, Przebudowaí czlowieka. Komunistyczne wysitki zmiany mentalności, TRIO, Warszawa 2001, s. 26.

11 Tamże, s. 27.

12 M. Brodala, A. Lisiecka, T. Ruzikowski, Przebudować człtowieka. Komunistyczne wysitki zmiany mentalności , dz. cyt., s. 59.

13 Tamże, s. 162. 
Fałszywość treści tego wierszyka, choćby $z$ punktu widzenia historycznego, jest dziś dla nas oczywista. Wszak to właśnie polskie władze słały transporty surowca $\mathrm{i}$ maszyn, a straty $\mathrm{z}$ tytułu wywozu samego węgla sięgnęły w ciagu pierwszych sześciu lat blisko 10 miliardów złotych. Jednakże w tamtych latach głoszenie takiej prawdy, było co najmniej nie wskazane.

Dla systemu totalitarnego mistyfikacja dyskursu, była nieodłącznym elementem działania politycznego. W 1937 roku Dymitr Maniulski, wówczas sekretarz komitetu wykonawczego Kominternu wygłosił taka oto mowę:

Towarzysze, jestem zmuszony odkryć aferę, która jest tak ciemna, brudna i nieprawdopodobna, iż jestem pewien, że o niczym podobnym nie słyszeliście dotychczas. W roku 1920, gdy bohaterska Czerwona Armia zbliżała się do bram Warszawy, poddał się nam polski pułk liczący 700 ludzi. Przyjęliśmy tych ludzi z radością, wiedząc, że wielu z pośród nich jest przyjaciółmi Sowietów, a nawet prawdziwymi komunistami. Wielu polskich żołnierzy wstapiło jako oficerowie lub komisarze polityczni do Czerwonej Armii, a cały szereg Polaków otrzymało wysokie stanowiska w sowieckiej administracji wojskowej. Jest rzeczą jasna, że wobec szczególnych okoliczności, w jakich pułk się nam poddał, mieliśmy zaufanie do tych Polaków. Nie sprawdziliśmy nigdy przeszłości tych 700 ludzi. I dlatego wpadliśmy w pułapkę, zgodnie z planem naszych wrogów.

Wrogowie nasi zwalczali nas często podstępem, lecz nigdy nie byli tak zręczni jak w wypadku tych 700 żołnierzy. Któż mógł przypuszczać, że wszyscy oni byli doskonale dobranymi i znakomicie do swej misji przygotowanymi szpiegami. To była prawdziwa armia szpiegów, którzy zajęli u nas kierownicze stanowiska i w przeciagu 17 lat knuli, nie napotykając na żadne przeszkody, swe ciemne spiski. Kto organizował ten niecny spisek? Oczywiście zdrajca socjalizmu, Piłsudski. ${ }^{14}$

Co bardziej ortodoksyjni mogliby do tego dodać, że stało się tak, jak przepowiedział i ostrzegał Lenin. Ale przecież zawsze sa tacy, którzy nieustannie usiłuja przeszkadzać. Nie inaczej było również $z$ historia Wszechzwiazzowej Komunistycznej Partii (bolszewików) - WKP(b), która to nieustannie walczyła z wszelkimi przeszkodami. I tak:

${ }^{14}$ Cyt. za: W. Pronobis, Świat i Polska w XX wieku, Editions Spotkania, Warszawa 1991, s. $124-5$. 
WKP(b) rosła i potężniała $\mathrm{w}$ zasadniczej walce $\mathrm{z}$ partiami drobnomieszczańskimi; wewnątrz ruchu robotniczego $-z$ eserowcami (a jeszcze wcześniej z ich poprzednikami - narodnikami), z mienszewikami, anarchistami, nacjonalistami burżuazyjnymi wszelkiej maści; wewnątrz zaś partii $-\mathrm{z}$ mienszewikami, oportunistycznymi prądami - trockistami, bucharinowcami, odchyleńcami nacjonalistycznymi i innymi grupami antyleninowskimi.

WKP(b) potężniała i hartowała się w rewolucyjnej walce z wszelkimi wrogami klasy robotniczej, z wszelkimi wrogami mas pracujących - obszarnikami, kapitalistami, kułakami, szkodnikami, szpiegami, z wszystkimi najmitami otoczenia kapitalistycznego. ${ }^{15}$

Polscy socjaliści mieli podobne problemy, aczkolwiek bardziej prozaiczne; także musieli walczyć... z atakiem zimy (o ironio, jakże silna była socjalistyczna socjalizacja, to przecież do dzisiaj wszelkie rządy demokratycznego już państwa walczą $z$ tym nieobliczalnym wrogiem). „Zima nie nadchodzi, nie panuje - atakuje, jak wróg. Jej ataki są tak silne i perfidne, że usprawiedliwiaja nieprzygotowanie, bałagan i bezradność. Są zaskoczeniem. Pisze i mówi się o niej tak, jakby w Polsce była zjawiskiem nadzwyczajnym, wybrykiem lagodnego śródziemnomorskiego klimatu, który nagle oszalał. Jakby stanowiła fakt bez precedensu" "16.

Kolejnym ich problemem, było złagodzenie trudnej sytuacji i pogodzenie tego z równoczesnym nagłaśnianiem, że wszystko jest wspaniale. Sformułowano więc dyskurs, który brzmiał mniej więcej tak: „sytuacja jest dobra, ale jeszcze nie beznadziejna”. „Zdanie to w pięknej i absurdalnej formie oddaje charakter pewnego typu przemówień i publicystyki, praktykowanej wówczas, gdy nie można powiedzieć po prostu, że jest świetnie, bo rażąco by się to kłóciło $z$ faktami, powszechna świadomością i wiedzą odbiorców, ale nie chce się jednocześnie przyznać, że rzeczy mają się fatalnie" ${ }^{\text {"17 }}$. Tak więc cały sens tego dyskursu był mniej więcej taki: ,jest bardzo dobrze, wszystko świetnie prosperuje i rozwija się, ale nie można jeszcze mówić o całkowitym upadku""18. Współcześni polscy socjaliści, tj. socjaldemokraci wszelkiej maści, wspaniale odwrócili powyższą retorykę. Mianowicie przedstawiali sytuację właśnie jako kompletnie beznadziejną: „Kraj znajduje się na skraju załamania gospodarczego”, „Rząd Jerzego Buzka nie panuje nad

${ }^{15}$ Cyt. za: M. Głowiński, Rytuat i demagogia..., dz. cyt., s. 34

16 Tenże, Peereliada, PIW, Warszawa 1993, s. 114.

${ }^{17}$ Tenże, Marcowe gadanie, POMOST, Warszawa 1991, s. 29.

18 Tamże, s. 30. 
sytuacja”, ,Jego cała strategia negocjacyjna z UE rozsypała się w proch", „Najgorszą rzeczą dla Polski jest trwanie jego rządu” itd. Oczywiście zrozumiałe jest, że opozycja przed wyborami wysuwa takie hasła. Można zrozumieć także, ze robi to miesiąc po zwycięskich dla siebie wyborach (tzw. taktyka rzucania sobie kłód pod nogi), ale kiedy słyszy się to jeszcze rok po wyborach, to absurdalność takiego zjawiska jest nie do zniesienia - Polak potrafi. Jestem pewien, że na koniec tej kadencji taka retoryka powróci nie jeden raz.

Absurdalność dyskursu jest jakoby wpisana w życie polityczne, czasami jest ona tym większa, im bardziej dąży do prawdziwości. Kiedy wskazywano Deng Xiaopingowi, twórcy nowych, urynkowionych Chin, na nierównomierny rozwój kraju powiedział: „Chodzi o to, by bogaty był cały naród, ale ktoś musi wzbogacić się pierwszy"19. Gdy zapytano argentyńskiego prezydenta Juana Perona, czy w rządzeniu krajem kieruje się wartościami czy pragmatyzmem, odpowiedział: „Kieruję się wartościami, ale moja pierwszą wartością jest pragmatyzm"20. Podobnym pragmatyzmem kieruje się prezydent Aleksander Kwaśniewski. Podczas ważenia się losów ustawy abolicyjnej na początku stwierdził: „Podpiszę tę ustawę”, po jakimś czasie powiedział: „Podpiszę tę ustawę z mieszanymi uczuciami”, w końcu pod wpływem potężnej krytyki doszedł do wniosku, że skieruje tę ustawę do Trybunału Konstytucyjnego.

Dyskurs polityczny wykorzystywany jest najczęściej do propagowania sukcesu poszczególnych rządów (natomiast w wypadku opozycji - do kreowania klęski). I tak sukcesem polskiego rządu w 1976 roku było wprowadzenie na rynek litrowych butelek na coca colę $z$ zakrętką zamiast kapsla ${ }^{21}$ - wszak mówienie o sukcesach ma pokrzepić ogólna świadomość i samopoczucie Polaków. Podobny sukces odniósł rząd Leszka Millera 13 grudnia 2002 roku po słynnej batalii kopenhaskiej.

Rząd polski został postawiony przed ściana, a premier Danii miał zamiar rzucić popielniczką w naszego premiera, gdy ten po raz czwarty zwrócił uwage na sprawę mleka. Te dramatyczne, wyczerpujące i pełne grozy negocjacje o mało by nie zostały zerwane, ponieważ Miller w pewnym momencie chciał wracać do Polski (był jednak pewien, że wszyscy przywódcy „Piętnastki” dogoniliby go na lotnisku). Negocjacje były bardzo dramatyczne, przypominały maraton sportowy. Ale trzeba było się spieszyć, bo pociag odjeżdżał; należało zachować elastyczność i być skłonnym do kompromisu. Nasz rząd negocjowal twardo do końca (zmieniono nawet zaplanowany program szczytu, notabene tak szczęśliwie, że konferencja prasowa polskiego rządu rozpoczęła się o godzinie 19:30!). Oczywiście byli i tacy, którzy uknuli spisek przeciwko naszemu rządowi - premier nie podal jednak do wiadomości publicznej, które kraje 'piętnastki'

${ }^{19}$ P. Gilert, „Rzeczpospolita”, nr 284, 2002.

20 „Polityka”, nr 38, 2001.

${ }^{21}$ M. Głowiński, Peereliada, dz. cyt., s. 13. 
go zawiązały. Istniały również podejrzenia, że nasz rząd może być permanentnie podsłuchiwany w trakcie wewnętrznych rozmów, dlatego też Miller rozmawiał z Kalinowskim na schodach. Negocjacje były bardzo dramatyczne, ale odnieśliśmy całkowity sukces. Premier powiedział: „Wszystkie postulaty z jakimi przyjechaliśmy do Kopenhagi zostały przyjęte”; wicepremier Kalinowski stwierdził: „Cele, które stawiałem, zostały osiagnięte; uważam, że spełniłem swoje zadanie”. Tadeusz Iwiński zakomunikował: „Miałem momenty zwatpienia, gdyż negocjacje były bardzo dramatyczne”, po czym dodał: „W sprawie mleka zapadła decyzja rewolucyjna” (skoro walczyliśmy o 11,4 mln ton mleka, a otrzymaliśmy 8,5 mln ton, to rzeczywiście decyzja była rewolucyjna). No, ale ważne, że wróciliśmy z tarczą i nie wsiedliśmy do byle jakiego pociagu. Na samej konferencji było widać po zachowaniach naszych negocjatorów trudy walki. Sam Prezes Rady Ministrów nie wyglądał najlepiej. Miller okazał się jednak odporny i rozpoczął konferencję słowami: „Po całodziennych, wyczerpujących i czasami wręcz dramatycznych negocjacjach...”, „Dziękuję moim rodakom za poparcie dla rządu. Wyrazy głębokiego szacunku i podziękowania składam dla Jego Świątobliwości Jana Pawła II. Jesteśmy świadkami głębokiego wzruszenia. Od polskiej Solidarności, która wywalczyła demokrację, doszliśmy do solidarności europejskiej.

[... swoista nowomowa].

Powyższe opowiadanie jest kompilacją tego, co mogliśmy usłyszeć i przeczytać zaraz po zakończeniu szczytu w Kopenhadze. Dyskurs, który przedstawiłem powyżej został skonstruowany i podbudowany na schemacie faktycznego, który kierowany był do nas ze środków masowego przekazu. Była to opowieść, która właśnie nie tyle mówiła o faktach, ile podsuwała ich oceny. Moim zaś celem nie było jedynie przedstawienie wszelkich manipulacji, które niewątpliwie się tutaj pojawiły, ale przede wszystkim, chciałem na podstawie tej egzemplifikacji przedstawić produkcję dyskursu prawdziwościowego i wynikająca z niej absurdalność oceny jego prawdziwości.

Dyskurs wykorzystywany do propagowania sukcesu jest rzecza naturalna, nawet wtedy, gdy rzeczywistość sukcesu jest - mówiąc eufemistycznie - dość problematyczna. W takich wypadkach korupcja dyskursu wydaje się być niewinnym oszustwem, wpisanym w działanie polityczne. Jednak istnieje dyskurs, który może być o wiele groźniejszy dla samych obywateli.

Jesteśmy właśnie tego świadkami. To, że po 11 września 2001 roku świat się zmienił, było dla minie tak komiczną retoryką, że posługiwałem się nią tylko w żartach. Dziś wydaje mi się, że przynajmniej w jednym punkcie się pomyliłem. Mianowicie zauważyłem, że zmienił się dyskurs polityczny, za nim zaś poszły czyny - i to bynajmniej nie chwalebne. Powstała i rozwija się nowa forma języka, która nazwałbym nowomovus geopolitikus. Pod pretekstem walki z terroryzmem, administracje Stanów Zjednoczonych, Federacji Rosyjskiej, Izraela i wiele innych, pozwalaja 
sobie na ograniczanie nie tylko wolności politycznych i osobistych, ale nawet wolności do życia. Dzięki prowadzeniu takiej retoryki można wszczynać wojny i prowokować konflikty, można skutecznie ograniczyć wolność słowa i prasy, można aresztować każdego bagażowego, pilota czy instruktora, a wraz z nim jego babkę, dziadka, brata, siostrę, ojca i matkę, ponieważ łudząco przypominają muzułmańskich terrorystów. Wreszcie można nawet zabić niewinnych ludzi. Winnych zaś i podejrzanych traktuje się w dwojaki sposób: albo ich się lekko torturuje (tak dzieje się w światyni wolności i praw obywatelskich, USA), albo nieprzytomnym kobietom przystawia się pistolet do skroni i zabija (tak z kolei działaja agenci rosyjskiego Specnazu). To wszystko świadczy o ogromnej potędze dyskursu politycznego. Tworzy go i dystrybuuje władza i to stanowi jeden z największych jej atrybutów.

Jednakże, żeby zdobyć władzę i stać się największym dystrybutorem dyskursu, należy stworzyć wysublimowany rodzaj „języka wyborów” (przynajmniej w państwach demokratycznych), dzięki któremu pokonamy kontrkandydatów i przekonamy wyborców do swojej osoby. Tak na przykład w ostatnich wyborach samorządowych w Polsce dominowały słowa: „uczciwy” i „kompetentny” - skala tego hasła była tak ogromna, że łatwo można było dojść do konstatacji, że wszyscy kandydaci są równocześnie uczciwi i zarazem kompetentni. Z takim zamieszaniem poradziła sobie „Odnowa”22 - pismo społeczne katolików z Torunia. Do pisma dołączono ulotkę z tytułem: „Poradnik wyborczy dla każdego". W poradniku wypunktowano cała procedurę wyborcza: punkt pierwszy nakazywal przede wszystkim pójść na wybory; drugi zachęcał, aby przekonywać „wszystkich, których można”, trzeci głosił: „Pamiętajcie, nikt Was nie pogania”, ale już czwarty stwierdzał, że na karcie koloru różowego „głosujemy stawiając jeden krzyżyk przy nazwisku pana (...)" [w tym miejscu wskazane było nazwisko jednego z kandydatów na prezydenta miasta - przyp. P. B.], z kolei piąty, szósty i siódmy bardzo precyzyjnie wyjaśniały (przedstawiając wybrane nazwiska), w jaki sposób należy zagłosować do rady miasta, powiatu itd. Poradnik kończył się takimi oto słowami: „Jeśli już dokonaliście takiego wyboru, możecie udać się do domu i spożyć niedzielny obiad. Na pewno będzie smakował, bo po raz pierwszy od lat będziecie mieli poczucie tego, że dokonaliście naprawdę dobrego wyboru" [można by dodać, że jedynie słusznego wyboru! - P. B.].

\footnotetext{
22 Dalsze informacje i cytaty zostały zaczerpnięte z ulotki dołączonej do „Odnowy” -
} październik 2002, nr 35. 
Ciekawy dyskurs prowadzony był również w pierwszych wolnych wyborach prezydenckich III RP. Na przykład Stan Tymiński zawarł swój program wyborczy w 21 punktach i był to zbiór haseł w większości banalnych - pkt 13 brzmiał: „Rzeczpospolita Polska musi być krajem rządów prawa”, pkt 20: „Musimy bronić nasz kraj przed zatruciem środowiska"23. Opisując zaś to, co dzieje się w kraju, mówił: „Trwa wojna ekonomiczna, kraj zagrożony jest od wewnątrz i od zewnątrz" czy dalej „Jesteśmy bogatym krajem, mamy dużo surowców i wielu ludzi chcących pracować, którzy nigdy nie mieli możliwości pracy" lub: „Polska znowu może zostać mocarstwem"24. Dyskredytując swych kontrkandydatów stwierdzał: „Ludzie Mazowieckiego torturowali biskupa Karczmarka"25. Takim językiem posługiwał się Tymiński. Były to absurdy, w prawdziwość których uwierzyło kilka milionów Polaków.

W krajach anglosaskich dyskurs wyborczy prowadzony jest nieco inaczej, gdyż dla propagowania kandydatów „bardziej wartościowe i ważniejsze są krótkie, rytmiczne i najczęściej rymujące się frazy, które sa łatwe do zapamiętana i wyzwalają większe emocje"26. W trakcie kampanii skierowanej przeciwko Margaret Thatcher w Anglii, popularne stało się powiedzonko: Thatcher the milk snatcher ${ }^{27}$, co oznaczało, że pani premier jest rabusiem mleka. Była to aluzja do tego, że Thatcher, w latach 19701974 minister oświaty i nauki w rządzie Partii Konserwatywnej, zlikwidowała darmowe wydawanie goracego mleka uczniom brytyjskich szkół. Z wyborów prezydenckich w USA z 1968 roku pochodzi slogan: All the way with L.B.J., oznacza to wezwanie do poparcia kandydatury Johnsona, ale jeszcze w czasie tej samej kampanii można było usłyszeć: Hey, hey, hey, L.B.J., how many kids have you killed today? ? $^{28}$

Z dyskursem politycznym sa również związane pewne „wpadki”. Wszystko zależy w jakiej sytuacji i w jakich okolicznościach, a nawet, o której godzinie posługujemy się dyskursem. Na przykład Guenter Verhoygen, który dziękując pani premierowej za wspaniałą kolację dźwięcznie powiedział: Spasiba. Również bardzo zabawny okazał się być ostatnio przewodniczący rady miejskiej w Olsztynie, który podczas ślubowania kazał przysięgać radnym „na wierność Rzeczpospolitej Polskiej... Ludowej”. Tak więc humanizm socjalistyczny i wszelkie

${ }^{23}$ Cyt. za: J. Raciborski, Polskie wybory. Zachowania wyborcze społeczeństwa polskiego w latach 1989-1995, Warszawa 1999, s. 65.

24 Tamże.

25 Tamże, s. 67.

${ }^{26}$ O. Thomson, Historia propagandy, KiW, Warszawa 2001, s. 77

27 „Iron Lady” - z filmu o M. Thatcher.

${ }^{28}$ O. Thomson, Historia propagandy, dz. cyt., s. 77. 
opowieści o sześcioletnim planie i sześcioletnim Bronku, tudzież inne wierszyki o patriotyzmie i o wierności ludu pracującego miast i wsi, zostały zinternalizowane, u niektórych tkwią do dzisiaj - z mniejszą lub większą świadomościa. Nowomowa, o której pisał George Orwell ${ }^{29}$ bynajmniej nie zakończyła się z chwila, gdy staliśmy się państwem demokratycznym, ona trwa nadal...

Język polityki jest podstawowym narzędziem wykorzystywanym w działaniu politycznym, jest również nieodłącznym atrybutem władzy, która pragnie całkowitego zawładnięcia nim, która zawsze dąży do przedstawienia swojego dyskursu w sposób wskazujący za wszelką cenę jego prawdziwość - nawet za cenę absurdalności. „W naszych czasach polityczne przemówienia i publikacje stały się w dużej mierze obrona tego, co do obrony się nie nadaje (...) Wobec tego, język polityczny musi składać się głównie z eufemizmów, chwytów pozwalających omijać drażliwe pytania i zwykłej jałowej gadaniny"30. Dzisiejszy dyskurs polityczny odgrywa rolę dokładnie odwrotną niż ta, którą tradycyjnie przeznaczano retoryce. „Składa się wyłącznie z plakatowych haseł, które nie maja nic wspólnego $\mathrm{z}$ gromadzeniem, porządkowaniem czy wyjaśnianiem informacji bądź idei. Za pomocą współczesnego języka politycznego nie przekazuje się informacji, tylko je ukrywa lub zniekształca, nie zwraca publicznej uwagi na zasadnicze kwestie, tylko ja od nich odrywa i tłumi"31. Dyskurs polityczny zreifikował się. Tak bardzo chcieliśmy go opanować, lecz on opanował nas; ale wszystko, co przez człowieka zostało stworzone - nie jest wyższe od człowieka przez człowieka też opanowanym być możesz. ${ }^{32}$

${ }^{29}$ G. Orwell, Rok 1984, DC, Warszawa 1994.

${ }^{30}$ Cyt. za: R. E. Denton Jr., G. C. Woodward, Jak zdefiniować komunikacje polityczna, w: Wtadza i społeczeństwo, J. Szczupaczyński, dz. cyt., s. 200.

${ }^{31}$ Cyt. za: Tamże, s. 200.

32 S. Brzozowski, Idee, Wydawnictwo Literackie, Kraków 1990, s. 85. 